\title{
PROFILE OF USERS OF AMBULATORY AND HOSPITAL SERVICES
}

Flávio Alberto Oliva Oliva, Maria Lúcia Ribeiro, Marina Armelin Silva, Marjori Leiva Camparoto, Telma Reginato Martins

Universidade do Oeste Paulista - UNOESTE, Presidente Prudente, SP. e-mail: flavioaoliva@gmail.com

\begin{abstract}
The goal of this study was to understand the gender and age profile of the users of ambulatory services at public hospital. Gender and age are fundamental elements for the construction of public policies at local and regional level. We performed a 3-year retrospective data collection, regarding age and gender of the population of the outpatient clinic of the public hospital between 2013 and 2015. It is a research with quantitative approach performed through three databases from january 2013 to December 2015 totaling 460.505 consultations. The database of the public hospital was adopted as the primary source, it was also consulted the database of the last two censuses of the Brazilian Institute of Geography and Statistics (IBGE) and the database of the Regional Health Division. The cross-checking of data, through Microsoft Excel and the Online Analytical Processing (OLAP) software, allowed the construction of a graph structured by gender and age according to the standards defined by IBGE on 2010, as well as the comparison between age and gender profile of the total population attended by public hospital and its consultations. The female audience represents $60.5 \%$ of the attendances, while the male population accounts for $39.5 \%$. Only in the age groups between 0 and 14 and 85 to 89 years the male audience is larger. The difference in care is accentuated in the middle of the pyramid, in the ranges between 30 and 69 years, during which time women are responsible for $65.5 \%$ of the attendances against $34.5 \%$ of men. Such gender proportional differences are maintained on the total population, the only significant variation is on the age group from 80 and older where although there is a female majority of users, there is also a larger female majority on the population. Studies show that women make more references to health problems than men, as these represent, according to the male imagination, virility and strength, not representing vulnerability to the disease. Men do not recognize themselves as targets of health care and they are less likely to seek health services for cultural reasons, mainly, opening space for discussion about social inequalities in health between men and women.
\end{abstract}

Keywords: outpatient medical, unified health system, ambulatory care, public health, health care.

\section{PERFIL DE USUÁRIOS DE SERVIÇOS AMBULATORIAIS E HOSPITALARES}

\section{RESUMO}

O objetivo deste estudo foi compreender o perfil de gênero e idade dos usuários dos serviços ambulatoriais de um hospital público. Gênero e idade são elementos fundamentais para a construção de políticas públicas em nível local e regional. Foi realizada uma coleta de dados retrospectiva de três anos referente à idade e sexo da população do ambulatório e do pronto socorro entre 2013 e 2015. É uma pesquisa com abordagem quantitativa realizada por meio de três bases de dados no período de janeiro de 2013 a dezembro de 2015, totalizando 460.505 atendimentos. A base de dados do hospital foi adotada como fonte primária, também foi consultada a base de dados dos dois últimos censos do Instituto Brasileiro de Geografia e Estatística (IBGE) e a base de dados da Divisão Regional de Saúde. O cruzamento de dados, por meio do Microsoft Excel e do software Online Analytical Processing (OLAP), permitiu a construção de um gráfico estruturado por gênero e idade de acordo com os padrões definidos pelo IBGE em 2010, bem como a comparação entre idade e gênero e perfil da população total atendida. O público feminino representa $60,5 \%$ dos atendimentos, enquanto a população masculina responde por $39,5 \%$. Apenas nas faixas etárias 
de 0 a 14 e 85 a 89 anos o público masculino é maior. A diferença no atendimento se acentua no meio da pirâmide, nas faixas entre 30 e 69 anos, período em que as mulheres são responsáveis por $65,5 \%$ dos atendimentos contra $34,5 \%$ dos homens. Essas diferenças proporcionais de gênero são mantidas na população total, a única variação significativa é na faixa etária a partir de 80 anos onde, embora ocorra a maioria feminina de usuários, ocorre também a maioria feminina na população. Estudos mostram que as mulheres fazem mais referências aos problemas de saúde do que os homens, pois estes representam, segundo o imaginário masculino a virilidade e a força, não representando vulnerabilidade às doenças. Os homens não se reconhecem como alvos dos cuidados em saúde e têm menor probabilidade de procurar os serviços de saúde por questões culturais, principalmente, abrindo espaço para a discussão sobre as desigualdades sociais em saúde entre homens e mulheres.

Palavras-chave: ambulatório médico, sistema único de saúde, atenção ambulatorial, saúde pública, atenção à saúde.

\section{INTRODUCTION}

A health model that only increases the number of services without regard for efficiency, such as seen today, is not the best way to consolidate the Brazilian Unified Health System. Since such model facilitates the creation of a vicious circle in which the costs will inevitably only increase, innovation is need. The social process present in the contemporary world have induced great changes, such as the profile of the age pyramid and the change social, demographic, and environmental problems it is adamant to renew Unified Health System health model ${ }^{1}$.

Health innovation should not be understood only as an assemble of scientific, technological and economic knowledge, but also as an alternative to respond, in an effective way, the needs of the population through actions in the community, changes to the work environment and dialogue between the community and the professionals involved ${ }^{2}$. Thus, demands for health services cannot be solved simply by increasing monetary supply indiscriminately. Faced with this assertion, heath services need to adopt a set of new procedures aiming at paying full, efficient, and equitable health assistance ${ }^{3}$.

One of the arguments presented for the excessive demand in the hospital emergency/urgency services is the majority use of Unified Health System for problems which could be solved in basic or specialized care services or, in emergency services of less complexity. This demand profile is one of the main entry points into the health system and possibly reveals, among other things, unequal distribution of services, not only quantitatively, but also qualitatively, in basic and specialized care, as well as hospitals. In this context, Unified Health System created the National Humanization Policy (PNH) "Humaniza SUS", which brings, as a principle, the use of evaluation and classification of risk as one of the potentially decisive interventions in the reorganization and implementation of network health promotion ${ }^{4}$. However, the mandatory health assistance still enables patients with less complex problems to use hospitals, increasing Unified Health System costs.

According to literature, access to specialized centers is often difficult and can involve large displacement, high cost, lack of adequate information, delay in attendance and resolution of complaints, as well as, subjection to contingencies that delay the treatment of their diseases. Patient misinformation and ignorance of the gender and age of health care users are good examples of this scenario, since in most places there is no specialized medical assistance leading to delays in medical care ${ }^{5}$.

In a study by Basch ${ }^{6}$, primary health care was recognized as an integral part, permanent and ubiquitous system of health care in all countries. The Alma Ata Conference established that the basic components are health education, environmental sanitation, maternal and child health programs, family planning, prevention of endemic diseases, adequate treatment of common diseases and injuries, provision of essential medicines a promotion of good nutrition?

In many countries including Cuba the family physicians who reside where they work are members of the community where they carry out their activities and it is for the benefit of this group that they act as agents of change, 
especially when there are environmental or social circumstances that need improvement. This integration of conventional medical services with social and environmental services fits the model provided in Alma-Ata ${ }^{8}$.

Regarding the care lines, which work through the therapeutic process, it is mandatory that the pact between managers in the various instances be carried out, respecting the process of regionalization of the health of each State. It is essential to establish an agreement for the functioning of these conformities between the managers as well as the coordinators and managers, related to information exchange between those who coordinate the Basic Care Units, the diagnostic and therapeutic support network, the emergency and hospital services of the Health Department ${ }^{9}$. The pact should be based on the idea that health services should be organized, with focus on the health user, to ensure that the flow between the different health services work. The organization of care lines should involve the actors who are involved in health care ${ }^{10}$.

The health actions should also be guided by the principle of humanization of care. Since technological resources, access, shelter and bond represent a relationship, this, understood as a set of knowledge, processes, and methods used as branch of activity in the health sector, the offered technologies and devices that are established among workers and users should work so that the health actions are more welcoming, agile and resolute ${ }^{11}$.

The work practices in basic care should include several technologies in an adequate manner, according with the patient's health needs. Such needs are the actions and health services that the subjects need in order to have better living conditions, without damage to the care that requires material technologies ${ }^{12}$. The strategies to deal with outpatient demand may be based on variability management, which implies identifying homogeneous sub-groups that can be functionally well managed ${ }^{13}$. This allows us to assist future projections of the use of human, material and technological resources.

Therefore, this study was carried out to characterize the user population of the health services structure of the outpatient clinic of the Public Hospital by gender and age, as well as to analyze the population's needs based on such characterization

\section{METHODOLOGY}

Data Source

As previously discussed, characterizing a community is of great relevance for the assistance and planning of public power actions. Database of public hospital was used as the primary source to analyze the volume of patients that access the outpatient service, the database of the last two censuses of IBGE, 2000 to 2010, to analyze the age and gender profile of the region served by the clinic and the database of the regional Health Division to quantify the outpatient services of the municipalities served by the outpatient clinic of public hospital.

\section{Designer of graphics}

The data set used in this study was extracted from a total of users of unified health system in period between 2013 and 2015. Crossing the data through Microsoft Excel and the Online Analytical Processing, software allowed the construction of a graph structured by gender and age following the standards defined by $\mathrm{IBGE}^{14}$. The multidimensional view consisted of consultations that provided data regarding the age and gender profile of the users of public hospital outpatient service. Furthermore, in order to enable the analyses of such population it was necessary to create the total population profile. For such purpose it was used the census from 2012 made by $\mathrm{IBGE}^{15}$. It was considered for purposes of this work the most significant population resident on the area attend by public hospital. Even thought it offers care service for 45 municipalities for outpatient, urgent and emergency care, the most significant of those, representing $99.31 \%$ of the outpatient consultations are the municipalities of Alfredo Marcondes, Alvares Machado, Anhumas, Caiabu, Caiua, Dracena, Emilianópolis, Estrela do Norte, Euclides da Cunha Paulista, Flora Rica, lepe, Indiana, Irapuru, João Ramalho, Junqueirópolis, Marabá Paulista, Martinópolis, Mirante do Paranapanema, Monte Castelo, Nantes, Narandiba, Nova Guataporanga, Ouro Verde, Panorama, Pauliceia, Piquerobi, Pirapozinho, Presidente Bernardes, Presidente Epitácio, Presidente Prudente, Presidente Venceslau, Quatá, Rancharia, Regente Feijó, Ribeirão dos Índios, Rosana, Sandovalina, Santa Mercedes, Santo Anastácio, Santo Expedito, São João do Pau D’Alho, Taciba, Tarabai, Teodoro Sampaio, and Tupi Paulista with are the municipalities 
considered for the pourpose of this article as the total population attended by public hospital.

Statistical analysis

Data were analyzed in terms of measures and size. The choice of this object was due to its size and importance in the geographical space in which the outpatient clinic of public hospital is inserted.

\section{RESULTS}

This study aimed to investigate the profile of the users of public hospital ambulatory services regarding gender and age. Besides providing care services for 45 municipalities, public hospital also participates in the permanent health education, integrating the teaching actions with assistance by means of projects for all the professionals in the health sector. The hospital serves as a field for the practice of teaching, research and extension, seeking to promote improvement in the conduction of health services through an inter-professional, regionalized performance, executed, therefore, in a team with emphasis on the users of unified health system.

Concerning the analysis in question, when considering only the visits to outpatient services in public hospital as presented on Table 1 , the total female audience represents $60.5 \%$ of the attendances, while the male population accounts for $39.5 \%$. The male audiences starts larger than the female on age 0 to 04 years old, with a $20.44 \%$ majority. The male prevalence decays gradually up until age 14 . From 15 years old up to 80 and older the female audience is larger, increasing gradually from 15 to 49 year old, when it reaches its greater percentage difference, $34.77 \%$ more women than men, such gap is maintained on the age group of 50 to 59 with $34.41 \%$, and starts decreasing its percentage majority over the male population on the 60 years old age group.

Table 1. Age and gender analyses of public hospital.

\begin{tabular}{lccccccc}
\hline Age Group & Female & Male & Total & \% Female & \% Male & \% Difference & $\begin{array}{c}\text { \% } \\
\text { Total }\end{array}$ \\
\hline $\mathbf{8 0}$ and older & 6.580 & 6.346 & 12.926 & 50.91 & 49.09 & 1.81 & 2.81 \\
$\mathbf{7 0}$ to $\mathbf{7 9}$ & 20.566 & 17.622 & 38.188 & 53.85 & 46.15 & 7.71 & 8.29 \\
$\mathbf{6 0}$ to $\mathbf{6 9}$ & 40.422 & 26.210 & 66.632 & 60.66 & 39.34 & 21.33 & 14.47 \\
$\mathbf{5 0}$ to $\mathbf{5 9}$ & 61.056 & 29.793 & 90.849 & 67.21 & 32.79 & 34.41 & 19.73 \\
$\mathbf{4 0}$ to $\mathbf{4 9}$ & 61.398 & 29.714 & 91.112 & 67.39 & 32.61 & 34.77 & 19.79 \\
$\mathbf{3 0}$ to $\mathbf{3 9}$ & 37.527 & 21.761 & 59.288 & 63.30 & 36.70 & 26.59 & 12.87 \\
$\mathbf{2 0}$ to $\mathbf{2 9}$ & 23.188 & 17.964 & 41.152 & 56.35 & 43.65 & 12.69 & 8.94 \\
$\mathbf{1 5}$ to $\mathbf{1 9}$ & 9.467 & 8.389 & 17.856 & 53.02 & 46.98 & 6.04 & 3.88 \\
$\mathbf{1 0}$ to $\mathbf{1 4}$ & 7.574 & 9.584 & 17.158 & 44.14 & 55.86 & 11.71 & 3.73 \\
$\mathbf{5}$ to $\mathbf{9}$ & 7.106 & 9.193 & 16.299 & 43.60 & 56.40 & 12.80 & 3.54 \\
$\mathbf{0}$ to $\mathbf{4}$ & 3.598 & 5.447 & 9.045 & 39.78 & 60.22 & 20.44 & 1.96 \\
\hline Total & 278.482 & 182.023 & 460.505 & 60.48 & 39.53 & - & 100 \\
\hline
\end{tabular}

Female and Male: total number of users of hospital sorted by sex regarding only each age group;

Total: number of users of hospital, male and female, of each age group;

$\%$ Female and \% Male: proportion of users of hospital for each sex and age;

$\%$ Difference: difference between the percentage of female and male users of hospital;

$\%$ Total: Percentage of each age group regarding the total number of users of hospital.

The age profile of the hospital outpatient users is also shown on Table 1. The percentage of group ages increases gradually up until $40-49$, representing $19.79 \%$ of the total users, decreases slightly on the 50-59 age group,
$19.73 \%$, and continues to decrease more significantly thenceforth. The majority of users are on the age group 30-69 years old, which represents $66.86 \%$ of the total users. Children, considered from 0-14 years old represent $9.23 \%$ 
of users, teenagers and young adults from 15 to 29 year old represent $12.81 \%$ of users and the elderly population, starting on 70 years old represent $11.10 \%$ of the total users.

The age pyramid shown on Figure 1 is significantly larger in the middle. There is also a considerable difference between female and male users on such portion. Therefore the user profile of public hospital, representing $34.74 \%$ of the total users are adult females from 30 to 59 years old.
It is evidenced that the character of preventive medicine is more present in the female audience as compared with the masculine. In consulting the official databases of the Ministry of Health, it is observed that in the year 2014, more than 3.3 billion outpatient procedures were performed in Unified Health System. The proportion reported in terms of complexity was $48 \%$ in primary care (outpatient), $31 \%$ in secondary care, $20 \%$ in tertiary care and $1 \%$ of non-applicable data ${ }^{13}$.

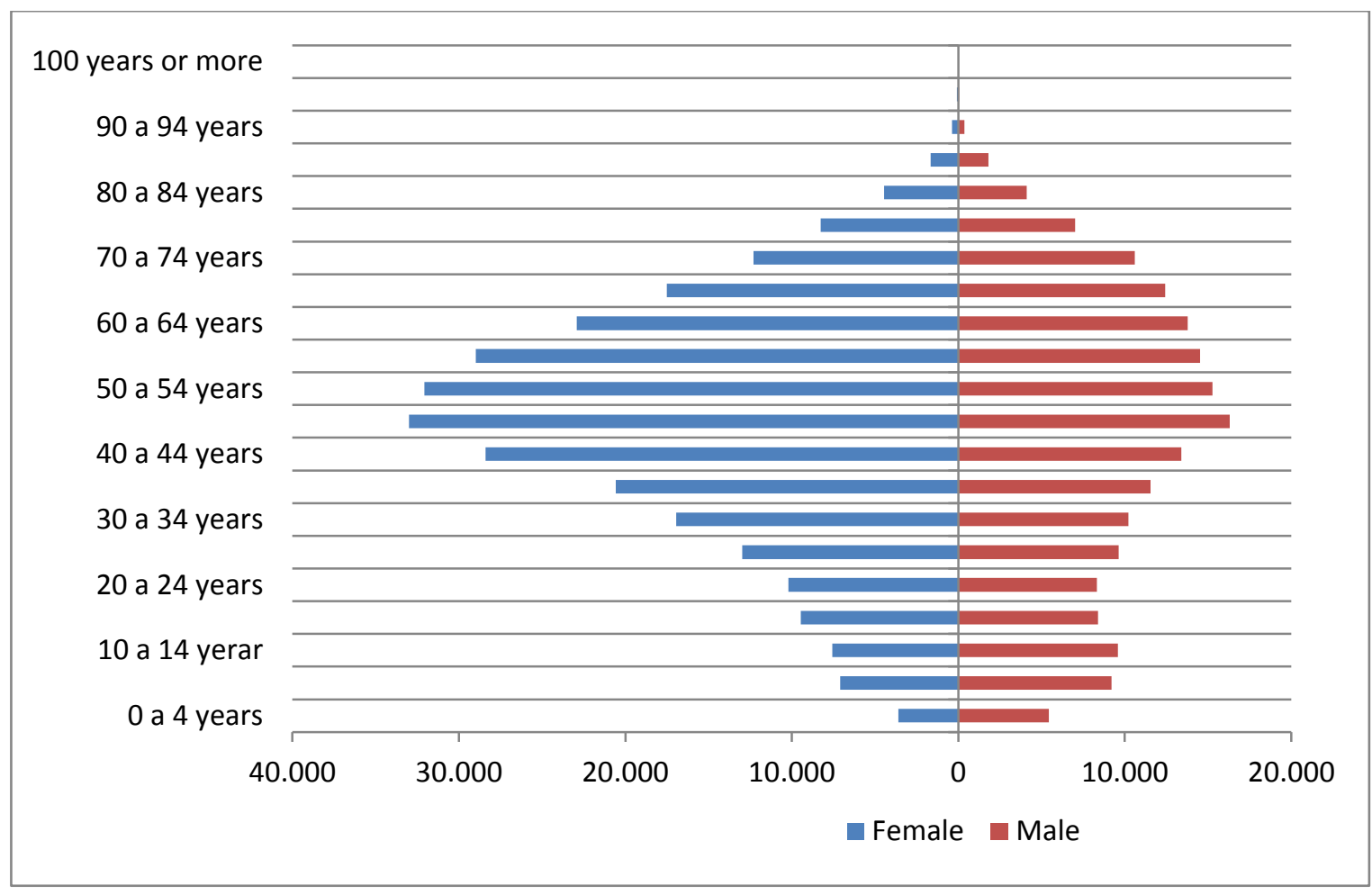

Figure 1. Age and gender pyramid of the outpatient clinic from 2013 to 2015.

Public Hospital user's age and gender profile cannot be analyzed separately from the total user population attended by hospital, therefore the data from 2012 population census projections was consolidated on Table $2^{15}$. This data lead to the conclusion that the gender and age difference is mostly maintained even when considering the data on Table 2 . When analyzing the combined age pyramid of most significant municipalities (Figure 2), even though it is also larger in the center and there is a majority of women, it is not as accentuated as the age pyramid of $\mathrm{PH}$. The percentage difference between hospital male and female population when subtracted from the male and female difference of the total population is shown on
Table 3, and even though there is a reduction of such difference in most age groups, it maintain the conclusions above. The only significant difference is on the age group from 80 and older, which even though is not significant for the user profile of hospital representing only $2.81 \%$ of the total users is relevant for a public health analysis. Although there is a female majority of users on such age group, there is also a larger female majority on the population, which when subtracted from the shows that, proportionally, $11.03 \%$ more males of the age group 80 and older use hospital outpatient clinic. 
Table 2. Gender and age of total population attended by public hospital.

\begin{tabular}{lccccccc}
\hline Age Group & Female & Male & Total & \% Female & \% Male & \% Difference & \% Total \\
\hline $\mathbf{8 0}$ and older & 8.199 & 6.331 & 12.926 & 56.43 & 43.57 & 12.86 & 2.81 \\
$\mathbf{7 0}$ to $\mathbf{7 9}$ & 17.605 & 15.305 & 38.188 & 53.49 & 46.51 & 6.99 & 8.29 \\
$\mathbf{6 0}$ to $\mathbf{6 9}$ & 28.938 & 25.318 & 66.632 & 53.34 & 46.66 & 6.67 & 14.47 \\
$\mathbf{5 0}$ to $\mathbf{5 9}$ & 42.649 & 38.306 & 90.849 & 52.68 & 47.32 & 5.36 & 19.73 \\
$\mathbf{4 0}$ to $\mathbf{4 9}$ & 54.456 & 51.795 & 91.112 & 51.25 & 48.75 & 2.50 & 19.79 \\
$\mathbf{3 0}$ to $\mathbf{3 9}$ & 55.590 & 56.015 & 59.288 & 49.81 & 50.19 & 0.38 & 12.87 \\
$\mathbf{2 0}$ to $\mathbf{2 9}$ & 57.549 & 62.060 & 41.152 & 48.11 & 51.89 & 3.77 & 8.94 \\
$\mathbf{1 5}$ to $\mathbf{1 9}$ & 29.000 & 30.475 & 17.856 & 48.76 & 51.24 & 2.48 & 3.88 \\
$\mathbf{1 0}$ to $\mathbf{1 4}$ & 27.944 & 28.906 & 17.158 & 49.15 & 50.85 & 1.69 & 3.73 \\
$\mathbf{5}$ to $\mathbf{9}$ & 23.234 & 24.770 & 16.299 & 48.40 & 51.60 & 3.20 & 3.54 \\
$\mathbf{0}$ to $\mathbf{4}$ & 21.319 & 22.358 & 9.045 & 48.81 & 51.19 & 2.38 & 196 \\
\hline Total & 366.483 & 361.639 & 460.505 & - & - & - & 100 \\
\hline
\end{tabular}

Female and Male: total number of users of hospital sorted by sex regarding only each age group;

Total: number of users of hospital, male and female, of each age group;

$\%$ Female and \% Male: proportion of users of hospital for each sex and age;

$\%$ Difference: difference between the percentage of female and male users of hospital;

$\%$ Total: Percentage of each age group regarding the total number of users of hospital.

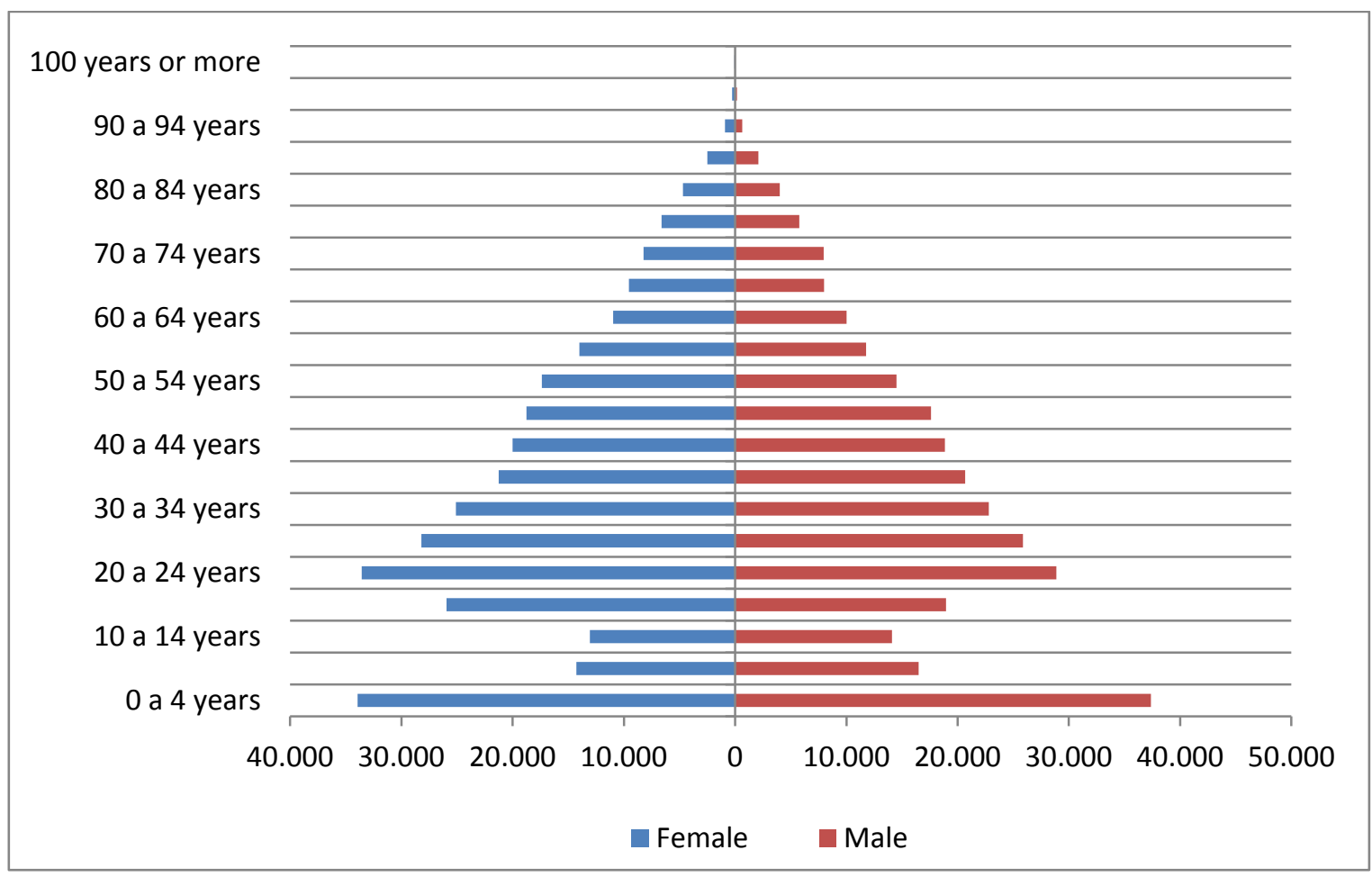

Figure 2. Age and gender pyramid of the total population attended in the emergency room at the public hospital. 
Table 3. Comparison between public hospital users and total population attended at public hospital.

\begin{tabular}{lcccccc}
\hline Age Group & TP & TPM & PH & PHM & \% Difference & Majority \\
\hline $\mathbf{8 0}$ and older & 12.86 & $\mathrm{~F}$ & 1.81 & $\mathrm{~F}$ & -11.05 & $\mathrm{~F}$ \\
$\mathbf{7 0}$ to $\mathbf{7 9}$ & 6.99 & $\mathrm{~F}$ & 7.71 & $\mathrm{~F}$ & 0.72 & $\mathrm{~F}$ \\
$\mathbf{6 0}$ to $\mathbf{6 9}$ & 6.67 & $\mathrm{~F}$ & 21.33 & $\mathrm{~F}$ & 14.66 & $\mathrm{~F}$ \\
$\mathbf{5 0}$ to $\mathbf{5 9}$ & 5.36 & $\mathrm{~F}$ & 34.41 & $\mathrm{~F}$ & 29.05 & $\mathrm{~F}$ \\
$\mathbf{4 0}$ to $\mathbf{4 9}$ & 2.50 & $\mathrm{~F}$ & 34.77 & $\mathrm{~F}$ & 32.27 & $\mathrm{~F}$ \\
$\mathbf{3 0}$ to $\mathbf{3 9}$ & 0.38 & $\mathrm{M}$ & 26.59 & $\mathrm{~F}$ & 26.97 & $\mathrm{~F}$ \\
$\mathbf{2 0}$ to $\mathbf{2 9}$ & 3.77 & $\mathrm{M}$ & 12.69 & $\mathrm{~F}$ & 16.46 & $\mathrm{~F}$ \\
$\mathbf{1 5}$ to $\mathbf{1 9}$ & 2.48 & $\mathrm{M}$ & 6.04 & $\mathrm{~F}$ & 8.52 & $\mathrm{~F}$ \\
$\mathbf{1 0}$ to $\mathbf{1 4}$ & 1.69 & $\mathrm{M}$ & 11.71 & $\mathrm{M}$ & 10.02 & $\mathrm{M}$ \\
$\mathbf{5}$ to $\mathbf{9}$ & 3.20 & $\mathrm{M}$ & 12.80 & $\mathrm{M}$ & 9.60 & $\mathrm{M}$ \\
$\mathbf{0}$ to $\mathbf{4}$ & 2.38 & $\mathrm{M}$ & 20.44 & $\mathrm{M}$ & 18.06 & $\mathrm{M}$ \\
\hline
\end{tabular}

TP: proportional gender difference on the total population attended by hospital;

TPM: gender of the majority of the total population attended by hospital;

$\mathrm{PH}$ : proportional gender difference on hospital users;

PHM: gender of the majority of hospital users;

\% Difference: proportional gender difference on hospital users minus total population attended by hospital when on the same gender and additional when on different genders, in order to calculate the proportional gender prevalence for each age.

\section{DISCUSSION}

The results found on Public Hospital agree with the national data since women are the majority of the Brazilian population and the main users of unified health system ${ }^{16}$. Furthermore similar results have been obtained on other researches regarding gender attendance on Brazilian hospitals. In other study with patients from the outpatient clinic of the Services Hospital in Rio de Janeiro, found a frequency of $72 \%$ of women, $48 \%$ married and $60 \%$ nursing mothers. As for men, $60 \%$ were married, $52 \%$ employed and $28 \%$ retired $^{17}$.

In a study by Silva et al. ${ }^{5}$ conducted on Porto Alegre, the analysis of the demographic data referring to the population of patients interviewed from March to July 2008 indicated a larger contingent of female patients (77.5\%), with a mean age of 52.5 years (less than 17 years of age and, more than 90 years). The comparative analysis of the mean age by sex did not show a statistically significant difference $(p=0.72)$.

The distribution of the visit is similar in different studies regarding the presence of majority of the female audience as compared with the male for outpatient care $\mathrm{r}^{5,13,17,18}$.

The existence of a female majority demands the analyses of two distinct points. The first is how to better meet women's need in health care and the second is to establish the reason for such prevalence, whether it is a natural phenomenon, there is an excess of women using the system or a lack of men. Regarding the first problem it is important to better understand the different traits concerning men and women. The gender difference involves not only biological aspects but also social ones ${ }^{19}$.

Therefore, in order to better meet women's demands it is necessary to consider the different biological aspects, regarding the exercise of their sexuality, women are extraordinary affected and due to their biological feature, have complications such as the vertical transmission of diseases such as syphilis and HIV, maternal mortality and other morbidities still not studied $^{16}$.

Also, there are other biological differences not related to the reproductive system, such as response to treatment. Preclinical studies showed than the sex hormones affect sex-specific immune responses in trauma patients. Male sex hormones are deleterious, whereas female hormones are protective. The same study shows that females have a lower rate of trauma complications but higher rate of acute respiratory distress syndrome as well as gender- 
based differences in quality of life and cognitive functioning after injury ${ }^{20}$.

However, the most important difference among men and women are not biological, but social. A study conducted by Yiko at al. ${ }^{21}$ showed that women with Acute Coronary Syndrome report significantly poorer health related quality of life than young men both in terms of physical and mental functioning.

Mental health issues also vary significantly from women and men. In Norway the probability of a psychiatric outpatient visit was significantly lower among men compared to women in ages 30-49 years, whereas the trend was the opposite for ages 50 years and over ${ }^{22}$.

In addition, it is also relevant for health service to provide patient satisfaction. In an American study comparing patient satisfaction in women's clinics versus traditional primary care clinics for veterans, it was shown that women who attended the women's clinics showed preference for those clinics due to flexibility in scheduling an appointment, patient dignity, communication (time allowed for talking and asking questions, sensitivity to patient issues) ${ }^{23}$. Even though those were female clinics, it is possible to adapt traditional primary care in order to encourage those aspects favored by women since they are the majority of patients.

Moreover, it is crucial to understand the reason for prevalence of female patients in order to implement social health programs that better serve the population needs. The difference could be a natural phenomenon, due to the biological differences between both genders; in which case it would be necessary to extend the female care program. Or it could be due to underutilization of primary care by men, which indicates the necessity to expand the male care program. It could also mean an over usage of the system by women, which could be burdening the health care program and therefore should be discouraged. Depending on the case, the answer to such question is important to create public policies.

An American study demonstrated that women have worse self-rated health and more hospitalization episodes than men from early adolescence to late middle age, but they are less likely to die at each age, which presents a paradox, and may suggest that both genders might have different assessments on their health. However, the study showed that women and men with the same sets of chronic conditions have the same self-rated health, which indicates that both have the same parameter for assessing their health ${ }^{24}$. Since the study indicates that women have worse self-rated health and that such assessment might be accurate it appoints to the possibility that women actually do have more health problem than men and, therefore, more need of health assistance.

Another possibility is the socially constructed refusal of men to seek outpatient clinics. If there is such a refusal it results in the individual being deprived of the protection required to preserve their health and continue to use unnecessary procedures differently if the search for attention had occurred. Many injuries can be avoided if men regularly perform primary prevention measures. Male resistance to primary care increases not only the financial burden of society but also, above all, the physical and emotional suffering of the patient and his family, in the struggle for the maintenance of the health and quality of life of these people.

Such point of view is corroborated with study German that showed poor glycemic control in patients with type 2 diabetes mellitus was more prevalent in men (23\%) than women (18\%), it also showed significantly fewer medical appointments, lower number of medications and longer rehabilitation stays in men than in women ${ }^{25}$.

Much of the non-adherence to health care measures by men is derived from cultural variables. Gender stereotypes rooted for centuries in our patriarchal culture potentiate practices based on beliefs and values of what it is to be masculine. The disease is considered a sign of fragility that men do not recognize as inherent in their own biological condition. Man thinks he is invulnerable, which results in less self-care and more exposure to situations of risk ${ }^{18}$. This is worsened by the individual's fears that the doctor could discover his bad health, thereby putting his belief of invulnerably at risk. In this work the data shows the male behavior in not seeking the special outpatient clinic.

Men are faced with the difficulty of recognizing their needs; they cultivate magical thinking that rejects the possibility of getting sick. In addition, the health care system usually provides services and communication strategies that focus on health actions for children, adolescents, women and elderlies. Furthermore, men pointed out that they do not to seek primary care services due to their position as provider. It 
is alleged that the hours of operation of the health services coincide with the workload. It cannot be denied that, in the male concern, the labor activity has a prominent place, especially in people of low social status, which reinforces the historically attributed role of the man being the provider for the family. Although this may often constitute an important barrier, the majority of women from all socio-economic categories, at the moment, are part of the productive force inserted in the formal labor market but not in any way fail to seek health care services ${ }^{9}$.

Although the concept of masculinity is currently being challenged and lost its original rigor in the dynamics of the cultural process ${ }^{18}$, the still prevalent and hegemonic conception of masculinity is could be the structuring axis for not seeking health services.

\section{CONCLUSIONS}

Public hospital main user's profile constitutes of women, manly adults from 30 to 69 years old, which is in accordance with the rest of the Brazilian territory. Therefore it is necessary to adapt primary care to better attend those women. It can be achieved with better communication by health providers, as well as more flexible hours.

Although in a wrong way, in our society, care is one of the roles considered as being feminine. So from an early age, women are educated to play and take responsibility of this role. The understanding of socio-cultural and institutional barriers is important for the strategic proposal of measures that promote the access of men to primary health care services, which should be the gateway to the health system, in order to safeguard prevention as necessary and fundamental axes of intervention. Therefore, public policies must be planned based on the demands of society, respecting the diversity and plurality of the profile of health service users.

There is also a demand for more works to better understand the reasons for the female prevalence. Even though it appoints to a social problem there is a lack of investigation on the other possibilities such as overuse of health system by women and biological difference, as well as, whether does men overburden urgency and emergency care.

To better understand the difference on primary care usage is fundamental for the promotion of equity among the population. In this perspective, the absence of specific policies results in pressure in different areas of the health system. The need for an ordering is essential and is conferred to the extent that there is a clear vocation for a specific type of care where the system should rely on this specialization to better target their demands.

\section{COMPETING INTERESTS}

The author declares that they have no competing interest.

\section{ACKNOWLEDGEMENT}

The authors would like to acknowledge the contribution of University of Araraquara for expert assistance with Program in Territorial Development and Environment, and the Ambulatory services at Hospital Regional de Presidente Prudente.

\section{REFERENCES}

1. Escrivão Júnior $A$. A epidemiologia e o processo de assistência à saúde. In: Neto GV, Malik AM. Gestão em saúde. Rio de Janeiro: Guanabara Koogan; 2012. p.115.

2. Lefebvre H. Lógica formal, lógica dialética. 2.ed. Rio de Janeiro: Civilização Brasileira; 1995.

3. Bourdieu P. O poder simbólico. 12.ed. Rio de Janeiro: Bertrand Brasil; 2009.

4. Oliveira GN, Silva MFN, Araújo IEM, Carvalho Filho MA. Perfil da população atendida em uma unidade de emergência referenciada. Rev Latino-Am Enferm. 2011;19(3):1-9.

5. Silva FA, Romagna ES, Silva MCA. Perfil dos pacientes adultos atendidos em ambulatório de reumatologia em um hospital geral em Porto AlegreRS. Rev AMRIGS. 2009; 53:257-60.

6. Basch PF. Textbook of international health. 6.ed. New York: Oxford University Press; 2012.

7. Mendes IAC. Desenvolvimento e saúde: a declaração de Alma-Ata e movimentos posteriores. Rev Latino-Am Enferm. 2004;12(3):447-8. DOI: https://doi.org/10.1590/S0104-11692004000300001

8. Gilpin M. Update Cuba: On the road to a family medicine nation. J Public Health Policy. 2010; 12:183203.

9. Franco CM, Franco TB. Linhas do cuidado integral: uma proposta de organização da rede de saúde. 2016. Acesso em 20 Fev 2017. Disponível em: http://www.saude.sp.gov.br/resources/humanizacao/ 
homepage/acesso-rapido/formacao-tecnica-emacolhimento-na-atencao-

basica/passo_a_passo_linha_de_cuidado.pdf

10. Gomes R, Nascimento EF, Araújo FC. Por que os homens buscam menos os serviços de saúde do que as mulheres? As explicações de homens com baixa escolaridade e homens com ensino superior. Cad Saúde Pública. 2007;23(3):565-74. https://doi.org/10.1590/S0102-311X2007000300015

11. Coelho MO, Jorge MSB. Tecnologia das relações como dispositivo do atendimento humanizado na atenção básica à saúde na perspectiva do acesso, do acolhimento e do vínculo. Ciên Saúde Coletiva. 2009;14(Suppl1):1523-31.

https://doi.org/10.1590/S1413-81232009000800026

12. Merhy EE. Saúde: a cartografia do trabalho vivo. Cad Saúde Pública. 2008;24(8):1953-5. https://doi.org/10.1590/S0102-311X2008000800023

13. Berg F, Faria AJA, Rosa JRM, Ramos MCA, Santos MW, Sousa MB, Pinto RM, Picoli RP. Desenvolvimento de metodologia para análise de serviços ambulatoriais em um hospital de ensino de alta complexidade. RAS. 2012;14(57):143-50.

14. IBGE. Censo 2010. Acesso em 05 Ago 2018. Disponível em: https://ww2.ibge.gov.br/home.estatistica/populacao/i ndic_sociosaude/2009/default.shtm

15. IBGE. Estimativas populacionais enviadas para o TCU, estratificadas por idade e sexo pelo MS/SGEP/Datasus. Brasília: IBGE; 2011-2012. Acesso em 24 Nov 2017. Disponível em: http://tabnet.datasus.gov.br/cgi/deftohtm.exe?ibge/c nv/popbr.def

16. Ministério da Saúde (Brasil), Secretaria de atenção à saúde, Departamento de ações programáticas estratégicas. Política nacional de atenção integral à saúde da mulher: princípios e diretrizes: Ministério da Saúde; 2004. 79p.

17. Rochedo MPRR, Guedes MAB. Perfil dos pacientes do ambulatório de clínica médica. Estudo preliminar. Rev Bras Clin. Med. 2010;8:33-36.

18. Keijzer B. Hasta donde el cuerpo aguante: género, cuerpo y salud masculina. In: Cáceres CF. et al. (Ed.) La salud como derecho ciudadano: perspectivas y propuestas desde América Latina. Lima: Universidad Peruana Cayetano Heredia; 2014. p.137-52.

19. Welzer-Lang D. A construção do masculino: dominação das mulheres e homofobia. Rev Estudos Feministas. 2001;9(2):460-82. https://doi.org/10.1590/S0104-026X2001000200008

20. Gomez D, Haas B, Mestral C, et al. Genderassociated diferences in access to trauma center care: a population-based analysis. Surgery. 2012;152:17985. https://doi.org/10.1016/i.surg.2012.04.006

21. Leung Yinko SS, Pelletier R, Behlouli $H$, Norris CM, Humphries $\mathrm{KH}$, Pilote L. Health-related quality of life in premature acute coronary syndrome: does patient sex or gender really matter? J Am Heart Assoc. 2014;3(4):e000901. https://doi.org/10.1161/JAHA.114.000901

22. Hansen $A H$, Hoye A. Gender differences in the use of psychiatric outpatient specialist services in tromso, Norway are dependent on age: a population-based cross-sectional survey. BMC Health Serv Res. 2015;15:477. https://doi.org/10.1186/s12913-015$\underline{1146-z}$

23. Bean-Mayberry BA, Chang $\mathrm{CCH}$, Neil MA, Whittle J, Hayes PM, Hudson Scholle S. Patient satisfaction in women's clinics versus traditional primary care clinics in the veterans administration. J Gen Intern Med. 2003;18:175-81. https://doi.org/10.1046/i.15251497.2003.20512.x

24. Case AC, Paxson C. Sex differences in morbidity and mortality. Demography. 2005; 42(2):189-214. https://doi.org/10.1353/dem.2005.0011

25. Kramer HU, Ruter G. Schottker B, Rothenbacher D, Rosemann T, Szcsenyi J, Brenner H, Raum E. Gender differences in healthcare utilization of patients with diabetes. Am J Management Care. 2012;18(7):362-9. 